\title{
Nitrous oxide in the surface layer of the tropical North Atlantic Ocean along a west to east transect
}

\author{
Sylvia Walter, Hermann W. Bange, and Douglas W. R. Wallace \\ Forschungsbereich Marine Biogeochemie, Leibniz-Institut für Meereswissenschaften (IFM-GEOMAR), Kiel, Germany \\ Received 10 March 2004; accepted 16 July 2004; published 5 October 2004.
}

[1] Nitrous oxide $\left(\mathrm{N}_{2} \mathrm{O}\right)$ was measured during the first German SOLAS (Surface Ocean - Lower Atmosphere Study) cruise in the tropical North Atlantic Ocean on board R/V Meteor during October/November 2002. About 900 atmospheric and dissolved $\mathrm{N}_{2} \mathrm{O}$ measurements were performed with a semi-continuous GC-ECD system equipped with a seawater-gas equilibrator. Surface waters along the main transect at $10^{\circ} \mathrm{N}$ showed no distinct longitudinal gradient. Instead, $\mathrm{N}_{2} \mathrm{O}$ saturations were highly variable ranging from $97 \%$ to $118 \%$ (in the Guinea Dome Area, $\left.11^{\circ} \mathrm{N}, 24^{\circ} \mathrm{W}\right)$. When approaching the continental shelf of West Africa, $\mathrm{N}_{2} \mathrm{O}$ surface saturations went up to $113 \%$. $\mathrm{N}_{2} \mathrm{O}$ saturations in the region of the equatorial upwelling (at $\left.0-1.5^{\circ} \mathrm{N}, 23.5-26^{\circ} \mathrm{W}\right)$ were correlated with decreasing sea surface temperatures and showed saturations up to $109 \%$. The overall mean $\mathrm{N}_{2} \mathrm{O}$ saturation was $104 \pm 4 \%$ indicating that the tropical North Atlantic Ocean is a net source of atmospheric $\mathrm{N}_{2} \mathrm{O}$. INDEX TERMS: 4820 Oceanography: Biological and Chemical: Gases; 0312 Atmospheric Composition and Structure: Air/sea constituent fluxes (3339, 4504); 0322 Atmospheric Composition and Structure: Constituent sources and sinks. Citation: Walter, S., H. W. Bange, and D. W. R. Wallace (2004), Nitrous oxide in the surface layer of the tropical North Atlantic Ocean along a west to east transect, Geophys. Res. Lett., 31, L23S07, doi:10.1029/2004GL019937.

\section{Introduction}

[2] Nitrous oxide $\left(\mathrm{N}_{2} \mathrm{O}\right)$ is an important atmospheric trace gas because it influences, directly and indirectly, the Earth's climate to a significant degree: In the troposphere, it acts as a greenhouse gas with a relatively long atmospheric lifetime [Intergovernmental Panel on Climate Change (IPCC), 2001] whereas in the stratosphere it is the major source for nitric oxide radicals, which are involved in one of the main ozone reaction cycles [World Meteorological Organization, 2003]. Published source estimates indicate that the world's oceans play a major role in the global budget of atmospheric nitrous oxide [IPCC, 2001]. Generally, oligotrophic areas seem to be near equilibrium with the atmosphere, whereas coastal and equatorial upwelling areas show enhanced $\mathrm{N}_{2} \mathrm{O}$ concentrations [Nevison et al., 1995; Suntharalingam and Sarmiento, 2000]. Here we present about 900 measurements of dissolved and atmospheric $\mathrm{N}_{2} \mathrm{O}$ during the first German SOLAS (Surface Ocean - Lower Atmosphere Study) cruise. It is the first high-resolution data set of $\mathrm{N}_{2} \mathrm{O}$ in the tropical North Atlantic Ocean along a West to East transect and it is complementary to previous

Copyright 2004 by the American Geophysical Union. 0094-8276/04/2004GL019937
$\mathrm{N}_{2} \mathrm{O}$ measurements of Oudot et al. [1990, 2002] and Weiss et al. [1992].

[3] The cruise took place on board R/V Meteor (expedition no. M55) from Willemstad (Curaçao, Netherl. Antilles) to Douala (Cameroon) from 12 October to 17 November 2002. The cruise track consisted of two main transects: (i) The West to East transect along $10-12^{\circ} \mathrm{N}$ covering the oligotrophic tropical North Atlantic Ocean and the continental shelf area of the West African coast off Guinea Bissau and (ii) a shorter West to East transect along the equatorial upwelling (Figure 1).

\section{Method}

[4] $\mathrm{N}_{2} \mathrm{O}$ was determined with a gas chromatograph equipped with an electron capture detector. Further details of the analysis system are described in Bange et al. [1996]. A series of measurements of atmospheric $\mathrm{N}_{2} \mathrm{O}$ and $\mathrm{N}_{2} \mathrm{O}$ in seawater-equilibrated air followed by two standards was repeated every $50 \mathrm{~min}$. Mixtures of $\mathrm{N}_{2} \mathrm{O}$ in synthetic air were used to obtain two-point calibration curves. The mixtures used contained $311.7 \pm 0.1$ and $346.5 \pm 0.2 \mathrm{ppb}$ $\mathrm{N}_{2} \mathrm{O}$, respectively. These are gravimetrically prepared gas mixtures (Deuste Steininger GmbH, Mühlhausen Germany) and have been calibrated against the NOAA (National Oceanic and Atmospheric Administration, Boulder, Co.) standard scale in the laboratories of the Air Chemistry Division of Max Planck Institute for Chemistry Mainz, Germany. The precision, calculated as the ratio of the standard deviation of the atmospheric measurements and the mean atmospheric mixing ratio, was $0.8 \%$.

[5] Seawater was pumped continuously from a depth of $4 \mathrm{~m}$ into a shower-type equilibrator developed by R. F. Weiss (Scripps Institution of Oceanography, La Jolla, Ca.). $\mathrm{N}_{2} \mathrm{O}$ concentrations $\left(C\right.$, in nmol $\left.\mathrm{L}^{-1}\right)$ were calculated by applying the solubility equation of Weiss and Price [1980]:

$$
C=\beta(T, S) x^{\prime} P,
$$

where $x^{\prime}$ is the measured $\mathrm{N}_{2} \mathrm{O}$ dry mole fraction, $P$ is the atmospheric pressure, and $\beta$ is the solubility coefficient, which is a function of the water temperature $(T)$ and salinity $(S)$. Time series of seawater temperature $(S S T)$, salinity, wind speed, and atmospheric pressure were obtained from the ship's records. Differences between the seawater temperature at the seawater intake and the continuously recorded water temperature in the equilibrator were corrected:

$$
C_{w}=C \beta\left(T_{e q}\right) / \beta(S S T)
$$

with $\beta(S S T)$ and $\beta\left(T_{e q}\right)$ representing the $\mathrm{N}_{2} \mathrm{O}$ solubility at seawater temperature and water temperature inside the 


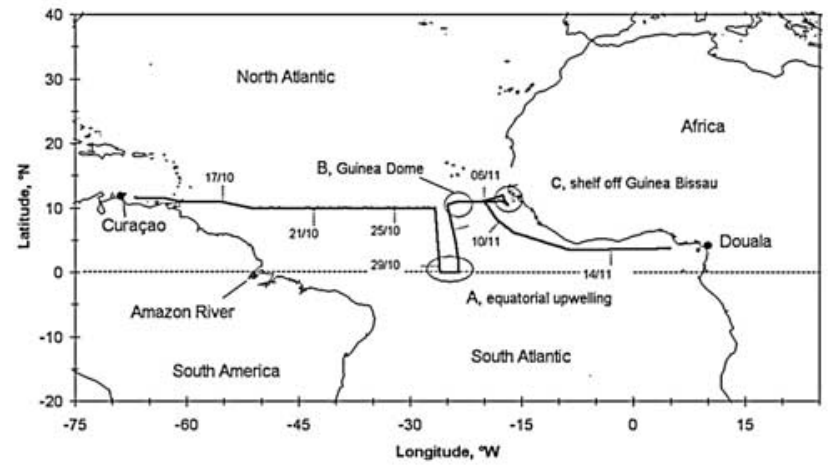

Figure 1. Cruise track of M55 in October-November 2002. $\mathrm{N}_{2} \mathrm{O}$ measurements were started 17 October and were finished 14 November. Areas of special interest discussed in the text are marked.

equilibrator at the time of the measurement, respectively. $\mathrm{N}_{2} \mathrm{O}$ saturations (Sat) in \% (i.e., $100 \%=$ equilibrium) were calculated as follows:

$$
\text { Sat }=100 C_{w} / C_{a}
$$

where $C_{a}$ is the equilibrium concentration of dissolved $\mathrm{N}_{2} \mathrm{O}$ based on the actual measurement of ambient air (see above). The mean relative errors of the $\mathrm{N}_{2} \mathrm{O}$ concentrations and saturations were calculated to be $1.2 \%$ and $1.6 \%$, respectively (details of the error propagation computation are given by Bange et al. [2001]).

\section{Results and Discussion}

[6] The mean atmospheric $\mathrm{N}_{2} \mathrm{O}$ dry mole fraction was $318 \pm 3 \mathrm{ppb}$. Due to the seasonal northward shift of the Intertropical Convergence Zone to about $10^{\circ} \mathrm{N}$, the origin of the air masses sampled during the cruise were from both the northern and the southern hemisphere. 4-days air mass back trajectories (provided by the German Weather Service, Offenbach, Germany) indicated that air masses sampled at latitudes south of $7^{\circ} \mathrm{N}$ originated from the southern hemisphere. Based on this classification we computed mean $\mathrm{N}_{2} \mathrm{O}$ values for northern and southern hemisphere air masses of $319 \pm 3 \mathrm{ppb}$ and $317 \pm 2 \mathrm{ppb}$, respectively. The observed atmospheric values are in agreement with $\mathrm{N}_{2} \mathrm{O}$ measurements at the baseline monitoring stations Ragged Point, Barbados and Cape Grim, Tasmania. Monthly mean values were 317 ppb (Cape Grim) and 318 ppb (Ragged Point) for October/November 2002. These values were taken from the Advanced Global Atmospheric Gases Experiment (AGAGE) data set (updated version from November 2003) [Prinn et al., 2000]. AGAGE data are available from the anonymous ftp site ftp://cdiac.esd.ornl.edu (subdirectory pub/ale_gage_Agage/Agage/gc-md/monthly) at the Carbon Dioxide Information Analysis Center in Oak Ridge, Tennessee.

[7] $\mathrm{N}_{2} \mathrm{O}$ saturations along the main cruise track ranged from $97 \%$ to $118 \%$ and the SST was generally between 27 and $30^{\circ} \mathrm{C}$ (Figure 2). Since the main cruise track was located between the eastward flowing North Equatorial Countercurrent (NECC) and the westward flowing North
Equatorial Current (NEC) [Stramma and Schott, 1999], we crossed several times meandering waters of different origins causing a high variability of the $\mathrm{N}_{2} \mathrm{O}$ saturation: Low $\mathrm{N}_{2} \mathrm{O}$ saturations of about $100 \%$ observed around 24 Oct., $27-$ 28 Oct., and 2 Nov. were generally associated with decreases in salinity (Figure 2). This results from the retroflection of the North Brazil Current, which advects Amazon plume waters (with low $\mathrm{N}_{2} \mathrm{O}$, see below) eastward into the NECC [Fratantoni and Glickson, 2002]. Freshwater influences were observed twice: First, at around $50^{\circ} \mathrm{E}$ (19 Oct., Figure 2) when we crossed the northern boundary of the Amazon river plume (minimum salinity 32.14 ) and second, on the continental shelf off West Africa where we measured a drop in salinity down to 31.30 (5-6 Nov., Figure 2). $\mathrm{N}_{2} \mathrm{O}$ saturations were not enhanced in the Amazon River plume, whereas an increase in $\mathrm{N}_{2} \mathrm{O}$ saturations up to $113 \%$ were observed on the West African shelf. The low $\mathrm{N}_{2} \mathrm{O}$ saturations in the Amazon River plume were attributed to the fact that $\mathrm{N}_{2} \mathrm{O}$-rich waters from the Amazon River are $\mathrm{N}_{2} \mathrm{O}$ depleted because of outgasing to the atmosphere and mixing with near-equilibrium oceanic waters while distributed to the North [Oudot et al., 2002]. The high $\mathrm{N}_{2} \mathrm{O}$ saturations on the continental African shelf might result from $\mathrm{N}_{2} \mathrm{O}$-rich riverine waters or groundwater seepage, but not from coastal upwelling as indicated by the uniform SSTs. $\mathrm{N}_{2} \mathrm{O}$ saturations up to $118 \%$ were observed in the area of the Guinea Dome at $11^{\circ} \mathrm{N}, 24^{\circ} \mathrm{E}(3-4$ Nov., Figure 2) which is well-known for pronounced Ekman upwelling [Siedler et al., 1992; Signorini et al., 1999]. In the equatorial region $\left(0-1.5^{\circ} \mathrm{N}, 28-30\right.$ Oct., Figure 2) SSTs dropped well below $27^{\circ} \mathrm{C}$ and were associated with enhanced $\mathrm{N}_{2} \mathrm{O}$ saturations (up to $109 \%$ ). We found a good

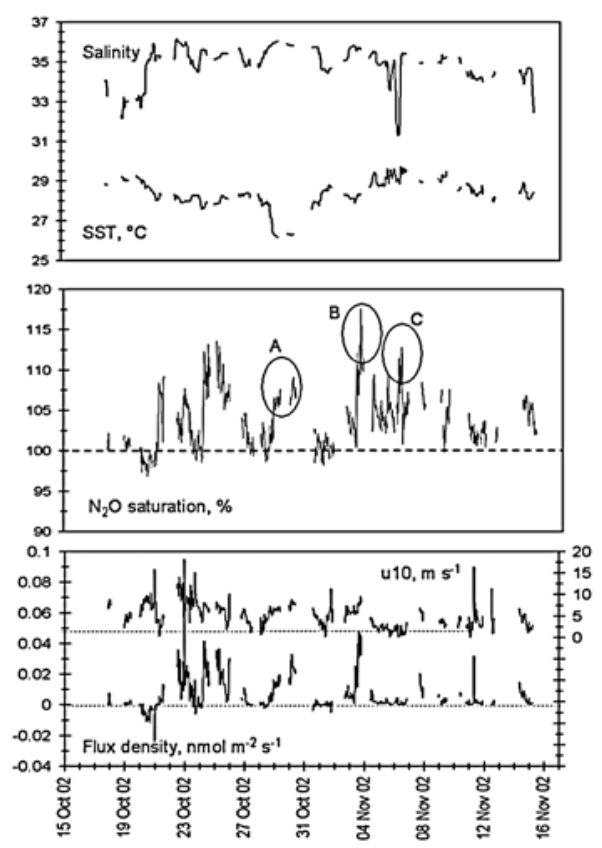

Figure 2. Salinity, seasurface temperature (SST), $\mathrm{N}_{2} \mathrm{O}$ saturation, wind speed in $10 \mathrm{~m}$ height ( $\mathrm{u} 10)$, and $\mathrm{N}_{2} \mathrm{O}$ flux density during M55. Area of special interest discussed in the text are marked (see Figure 1): A, equatorial upwelling; B, Guinea Dome; C, shelf off West Africa (water depths $<200 \mathrm{~m}$ ). 


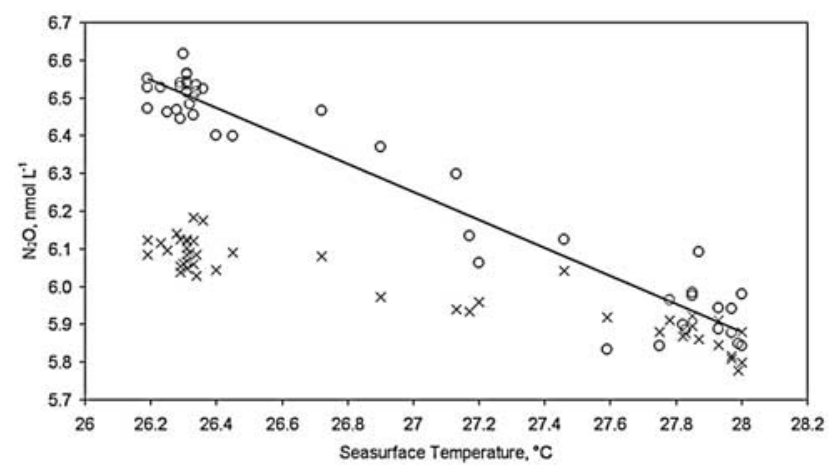

Figure 3. Correlation $\left(\mathrm{r}^{2}=0.94, \mathrm{n}=46\right)$ of SST and $\mathrm{N}_{2} \mathrm{O}$ concentration in the equatorial upwelling area $\left(0-2^{\circ} \mathrm{N}\right.$, $\left.23.5-26^{\circ} \mathrm{W}\right)$. Open circles stand for in-situ measurements and crosses stand for the corresponding equilibrium concentrations calculated as a function of the actual SST, Salinity, atmospheric dry mole fraction, and ambient pressure.

correlation between $\mathrm{N}_{2} \mathrm{O}$ concentrations and SST in the equatorial upwelling region (Figure 3 ) indicating that the enhanced surface $\mathrm{N}_{2} \mathrm{O}$ saturations were resulting from upwelling of $\mathrm{N}_{2} \mathrm{O}$-enriched subsurface waters.

[8] In order to account for the NECC/NEC system and the observed $\mathrm{N}_{2} \mathrm{O}$ features we defined two latitudinal aligned open ocean regions and a shelf region: 1) the tropical North Atlantic ranging from $1.5-12^{\circ} \mathrm{N}$ with SST $>27^{\circ} \mathrm{C}$, 2) the equatorial upwelling from $0-1.5^{\circ} \mathrm{N}$ with SST $<27^{\circ} \mathrm{C}$, and 3) the shelf area off the West African coast (water depth $<200 \mathrm{~m}$ ). An overview of the regional mean concentrations and saturations is given in Table 1. The mean $\mathrm{N}_{2} \mathrm{O}$ concentrations and saturations of the shelf and equatorial regions are significantly enhanced compared to the $1.5-12^{\circ} \mathrm{N}$ region. The high variability calculated for the tropical North Atlantic region is biased by the complex hydrography, which is influenced by the Amazon plume, the NECC/NEC system and the Guinea Dome upwelling with highly variable $\mathrm{N}_{2} \mathrm{O}$ concentrations. However, a more detailed regional analysis is hampered by the limited data set.

[9] Our data from the tropical North Atlantic are in agreement with previously published data. Recently, Oudot et al. [2002] reported a mean $\mathrm{N}_{2} \mathrm{O}$ saturation of $108 \pm 3 \%$, mainly measured along two transects at $7.5^{\circ} \mathrm{N}$ and $4.5^{\circ} \mathrm{S}$ during January-March 1993. They also observed a trend towards enhanced values when approaching the West African coast (up to $118 \%$ ). In a previous study in the Guinea Dome area during June-August 1986, Oudot et al. [1990] observed mean $\mathrm{N}_{2} \mathrm{O}$ saturations in the range from $126 \pm 5$ to $132 \pm 6 \%$ which are considerably higher than our results (Table 1). In the period from 1979 to 1989, Weiss et al. [1992] took part in several measurement campaigns with cruise tracks across the tropical North Atlantic Ocean. Their $\mathrm{N}_{2} \mathrm{O}$ measurements are in good agreement with the results presented here. For example, the mean $\mathrm{N}_{2} \mathrm{O}$ saturation during the first part of the TTO/TAS leg 3 in February 1983, which covered two transects along $9.5^{\circ} \mathrm{N}$ (from 20.25 to $28^{\circ} \mathrm{W}$ ) and $28^{\circ} \mathrm{W}$ (from 9.5 to the equator), was about $105 \%$. Enhanced values during TTO/TAS leg 3 were observed on the coast off Guinea-Bissau (up to $179 \%$ ) and in the equatorial upwelling (up to $111 \%$ ). In contrast to our measurements, the high $\mathrm{N}_{2} \mathrm{O}$ values observed off Guinea Bissau were caused by coastal upwelling (SST $<27^{\circ}$ ) [Weiss et al., 1992]. Summarizing the results from various $\mathrm{N}_{2} \mathrm{O}$ measurements in the open tropical North Atlantic, we found only slight differences (with the exception of the data from the Guinea Dome area by Oudot et al. [1990]). Significant differences as found for the Guinea Dome might be caused by seasonal variability of the circulation patterns [Stramma and Schott, 1999] in connection with different spatial data coverage. Since coastal upwelling was absent during our cruise, $\mathrm{N}_{2} \mathrm{O}$ saturations on the shelf off West Africa were comparably low.

\section{4. $\mathrm{N}_{2} \mathrm{O}$ Air-Sea Exchange}

[10] The air-sea exchange flux density $(F)$ was parameterized as

$$
F=k_{w}(u)\left(C_{w}-C_{a}\right),
$$

where $k_{w}$ (in $\mathrm{m} \mathrm{s}^{-1}$ ) is the gas transfer coefficient as a function of wind speed ( $u$ in $10 \mathrm{~m}$ height), $C_{w}$ is the measured $\mathrm{N}_{2} \mathrm{O}$ seawater concentration, and $C_{a}$ is the equilibrium $\mathrm{N}_{2} \mathrm{O}$ concentration in seawater based on the measured atmospheric value (for calculation of $C_{w}$ and $C_{a}$ see Methods section). To calculate $k_{w}$, we used the combined linear and quadratic $k_{w}-u$ relationship from Nightingale et al. [2000] (N00):

$$
k_{w}=9.2510^{-7} u+6.1710^{-7} u^{2} .
$$

The N00 relationship shows a dependence on wind speeds intermediate between the commonly used relationships of Liss and Merlivat [1986] and Wanninkhof [1992]. The measured wind speeds were normalized to $10 \mathrm{~m}$ height by using the relationship of Garratt [1977]. $k_{w}$ was adjusted by multiplying with $(S c / 600)^{-0.5}$, where $S c$ is the Schmidt number for $\mathrm{N}_{2} \mathrm{O}$. Sc was calculated using empirical

\begin{tabular}{|c|c|c|c|c|}
\hline & $\begin{array}{l}\text { Overall Mean } \\
(\mathrm{n}=451)\end{array}$ & $\begin{array}{l}0-1.5^{\circ} \mathrm{N} \\
(\mathrm{n}=27)\end{array}$ & $\begin{array}{l}1.5-12^{\circ} \mathrm{N} \\
(\mathrm{n}=416)\end{array}$ & $\begin{array}{l}\text { Shelf } \\
(\mathrm{n}=8)\end{array}$ \\
\hline $\begin{array}{l}\text { Concentration, } \\
\text { nmol L }\end{array}$ & $6.00 \pm 0.24$ & $6.49 \pm 0.07$ & $5.27 \pm 0.20$ & $6.31 \pm 0.11$ \\
\hline Saturation, \% & $104 \pm 4$ & $107 \pm 1$ & $103 \pm 3$ & $110 \pm 2$ \\
\hline $\begin{array}{l}\text { Flux density, } \\
\quad \mathrm{nmol} \mathrm{m}^{-2} \mathrm{~s}^{-1}\end{array}$ & $0.007 \pm 0.011$ & $0.018 \pm 0.006$ & $0.006 \pm 0.011$ & $0.002 \pm 0.002$ \\
\hline
\end{tabular}

Table 1. Mean $\mathrm{N}_{2} \mathrm{O}$ Concentrations, Saturations, and Flux Densities During M55 ${ }^{\mathrm{a}}$ 
equations for the kinematic viscosity of seawater [Siedler and Peters, 1986] and the diffusion coefficient of $\mathrm{N}_{2} \mathrm{O}$ in water. $\mathrm{N}_{2} \mathrm{O}$ diffusion coefficients $\left(D_{N 2 O}\right.$ in $\left.\mathrm{m}^{2} \mathrm{~s}^{-1}\right)$ were calculated with the equation derived from a compilation of actual measurements [Rhee, 2000]:

$$
D_{N 2 O}=3.16 \times 10^{-6} \exp (-18370 / R T)
$$

where $T$ is the water temperature in $\mathrm{K}$ and $R$ is the universal gas constant. The commonly used equation for $D_{N 2 O}$ by Broecker and Peng [1974] was replaced since Rhee's [2000] equation provides a more reasonable fit with a considerably reduced uncertainty of less than 10\% [Rhee, 2000]. Flux densities calculated with the above equation are lower by about 10\% when compared to computations with Broecker and Peng's [1974] equation [Bange et al., 2001]. We did not apply a correction of $D_{N 2 O}$ for seawater since the effect of seawater on the diffusion of dissolved gases is not uniform [King et al., 1995] and, to our knowledge, no measurements of the $\mathrm{N}_{2} \mathrm{O}$ diffusion in seawater have been published.

[11] The regional mean flux densities clearly reflect the interplay of saturation and wind speeds (Figure 2 and Table 1). In the equatorial region enhanced $\mathrm{N}_{2} \mathrm{O}$ saturations and comparably high wind speeds result in high flux densities, whereas over the shelf enhanced $\mathrm{N}_{2} \mathrm{O}$ saturations were associated with very low wind speed resulting in low flux densities (Figure 2). The mean flux density of the tropical North Atlantic region is biased by the high variability of both $\mathrm{N}_{2} \mathrm{O}$ saturations and wind speeds. The overall mean $\mathrm{N}_{2} \mathrm{O}$ flux density was $0.007 \pm 0.011 \mathrm{nmol}$ $\mathrm{m}^{-2} \mathrm{~s}^{-1}$ which is at the lower end of previously published flux densities: Oudot et al. [1990, 2002] computed overall mean flux densities of $0.013-0.021 \mathrm{nmol} \mathrm{m}^{-2} \mathrm{~s}^{-1}$ and $0.026 \pm 0.032 \mathrm{nmol} \mathrm{m}^{-2} \mathrm{~s}^{-1}$ for the tropical North and South Atlantic and the Guinea Dome area, respectively. The obvious discrepancy might be caused by different spatial data coverage, seasonal variability of the $\mathrm{N}_{2} \mathrm{O}$ concentrations and wind speeds, and the use of different approaches for the transfer coefficient $k_{w}$.

\section{Summary}

[12] $\mathrm{N}_{2} \mathrm{O}$ saturations in the tropical North Atlantic Ocean during October-November 2002 were highly variable and range from 97 to $118 \%$. The mean overall saturation was $104 \pm 4 \%$. Enhanced saturations were observed in the Guinea Dome area (up to $118 \%$ ), in the equatorial upwelling (up to $109 \%$ ), and the shallow continental shelf area off the West African Coast (up to 113\%). Our results are in agreement with previously published data sets. We found a good correlation of seawater temperature with $\mathrm{N}_{2} \mathrm{O}$ concentrations in the equatorial upwelling area. We conclude that the tropical North Atlantic Ocean is a net source of $\mathrm{N}_{2} \mathrm{O}$ to the atmosphere with a pronounced regional variability.

[13] Acknowledgments. We thank A. Körtzinger and M. O. Andreae for technical support and acknowledge the help of the other M55 participants and the officers and crew of R/V Meteor. We especially thank R. Hoffmann for the calibration of our standards and two anonymous reviewers for their valuable comments. We are indebted to the authorities of Guinea-Bissau for permission to work in their territorial waters. The investigations were financially supported by the Deutsche Forschungsgemeinschaft through grants WA1434/1 and WA1434/3.

\section{References}

Bange, H. W., S. Rapsomanikis, and M. O. Andreae (1996), The Aegean Sea as a source of atmospheric nitrous oxide and methane, Mar. Chem., $53,41-49$.

Bange, H. W., M. O. Andreae, S. Lal, C. S. Law, S. W. A. Naqvi, P. K. Patra, T. Rixen, and R. C. Upstill-Goddard (2001), Nitrous oxide emissions from the Arabian Sea: A synthesis, Atmos. Chem. Phys., 1, 61-71.

Broecker, W. S., and T.-H. Peng (1974), Gas exchange rates between air and sea, Tellus, 26, 21-35.

Fratantoni, D. M., and D. A. Glickson (2002), North Brazil Current ring generation and evolution observed with SeaWiFS, J. Phys. Oceanogr., $32,1058-1074$

Garratt, J. R. (1977), Review of the drag coefficients over oceans and continents, Mon. Weather Rev., 105, 915-929.

Intergovernmental Panel on Climate Change (2001), Climate Change 2001: The Scientific Basis: Contribution of Working Group I to the Third Assessment Report of the Intergovernmental Panel on Climate Change (IPCC), 881 pp., Cambridge Univ. Press, New York.

King, D. B., W. J. De Bryun, M. Zheng, and E. S. Saltzman (1995), Uncertainties in the molecular diffusion coefficient of gases in water for the estimation of air-sea exchange, in Air-Water Gas Transfer, edited by B. Jähne and E. C. Monahan, pp. 13-22, Aeon Verlag, Hanau, Germany.

Liss, P. S., and L. Merlivat (1986), Air-sea exchange rates: Introduction and synthesis, in The Role of Air-Sea Exchange in Geochemical Cycling, edited by P. Buat-Ménard, pp. 113-127, D. Reidel, Norwell, Mass.

Nevison, C. D., R. F. Weiss, and D. J. Erickson III (1995), Global oceanic emissions of nitrous oxide, J. Geophys. Res., 100, 15,809-15,820.

Nightingale, P., G. Malin, C. S. Law, A. J. Watson, P. S. Liss, M. I. Liddicoat, J. Boutin, and R. C. Upstill-Goddard (2000), In situ evaluation of air-sea gas exchange parameterizations using novel conservative and volatile tracers, Global Biogeochem. Cycles, 14, 373-387.

Oudot, C., C. Andrie, and Y. Montel (1990), Nitrous oxide production in the tropical Atlantic Ocean, Deep Sea Res., 37, 183-202.

Oudot, C., P. Jean-Baptiste, E. Fourré, C. Mormiche, M. Guevel, J.-F. Ternon, and P. Le Corre (2002), Transatlantic equatorial distribution of nitrous oxide and methane, Deep Sea Res., Part I, 49, 1175-1193.

Prinn, R. G., et al. (2000), A history of chemically and radiatively important gases in air deduced from ALE/GAGE/AGAGE, J. Geophys. Res., 105, $17,751-17,792$.

Rhee, T. S. (2000), The process of air-water gas exchange and its application, Ph.D. thesis, Texas A\&M Univ., College Station.

Siedler, G., and H. Peters (1986), Properties of sea water, in Oceanography, Landolt-Börnstein New Ser, vol. 3a, edited by J. Sündermann, pp. $233-$ 264, Springer-Verlag, New York.

Siedler, G., N. Zangenberg, R. Onken, and A. Morlière (1992), Seasonal changes in the tropical Atlantic circulation: Observation and simulation of the Guinea Dome, J. Geophys. Res., 97, 703-715.

Signorini, S. R., R. G. Murtugudde, C. R. McClain, J. R. Christian, J. Picaut, and A. J. Busalachhi (1999), Biological and physical signatures in the tropical and equatorial Atlantic, J. Geophys. Res., 104, 18,36718,382 .

Stramma, L., and F. Schott (1999), The mean flow field of the tropical Atlantic Ocean, Deep Sea Res., Part II, 46, 279-303.

Suntharalingam, P., and J. L. Sarmiento (2000), Factors governing the oceanic nitrous oxide distribution: Simulations with an ocean general circulation model, Global Biogeochem. Cycles, 14, 429-454.

Wanninkhof, R. (1992), Relationship between wind speed and gas exchange over the ocean, J. Geophys. Res., 97, 7373-7382.

Weiss, R. F., and B. A. Price (1980), Nitrous oxide solubility in water and seawater, Mar. Chem., 8, 347-359.

Weiss, R. F., F. A. Van Woy, and P. K. Salameh (1992), Surface water and atmospheric carbon dioxide and nitrous oxide observations by shipboard automated gas chromatography: Results from expeditions between 1977 and 1990, Rep. NDP-044, Carbon Dioxide Info. Anal. Cent., Oak Ridge Natl. Lab., Oak Ridge, Tenn.

World Meteorological Organization (2003), Scientific Assessment of Ozone Depletion: 2002, 498 pp., World. Metereol. Organ., Geneva.

H. W. Bange, D. W. R. Wallace, and S. Walter, Forschungsbereich Marine Biogeochemie, Leibniz-Institut für Meereswissenschaften (IFMGEOMAR), Düsternbrooker Weg 20, D-24105 Kiel, Germany. (hbange@ ifm-geomar.de) 